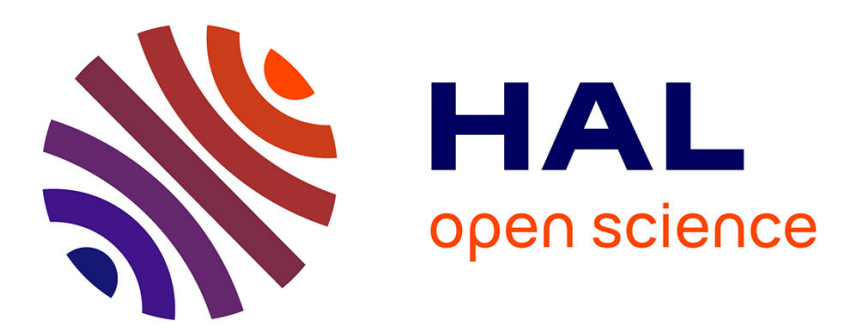

\title{
Entertainment and Instruction as Models in the Early Years of Animated Film: New Perspectives on Filmmaking in France
}

Valérie Vignaux

\section{- To cite this version:}

Valérie Vignaux. Entertainment and Instruction as Models in the Early Years of Animated Film: New Perspectives on Filmmaking in France. Animation, 2011, 6, pp.177 - 192. 10.1177/1746847711407408 . halshs-01109060

\section{HAL Id: halshs-01109060 \\ https://shs.hal.science/halshs-01109060}

Submitted on 30 Jan 2015

HAL is a multi-disciplinary open access archive for the deposit and dissemination of scientific research documents, whether they are published or not. The documents may come from teaching and research institutions in France or abroad, or from public or private research centers.
L'archive ouverte pluridisciplinaire HAL, est destinée au dépôt et à la diffusion de documents scientifiques de niveau recherche, publiés ou non, émanant des établissements d'enseignement et de recherche français ou étrangers, des laboratoires publics ou privés. 


\section{Entertainment and Instruction as Models in the Early Years of Animated Film, New Perspectives on Filmmaking in France by Valérie Vignaux}

Most essays devoted to animated film belong to one of two camps: general histories ${ }^{\mathrm{i}}$ or scholarly monographs. Those in the first camp treat the major film animators in terms of their filmography, whereas those in the second, because each of them is focussed on a single artist, pay scant attention ${ }^{\text {ii }}$ to any relations that there may be between animated and live-action film, much less between animation and other artistic genres, such as print illustration, comic strips, theatre, and cultural objects (toys, games, and books) designed for children. Research devoted to Emile Cohl, Marius O'Galop, and Robert Lortac, funded by the Association française de recherches sur l'histoire du cinéma and published in its review, 1895 , ${ }^{\text {iii }}$ have made it possible to describe what undoubtedly constitutes the first school or generation of film animators in France.

The collective analysis of these French animators' films - akin on both factual and aesthetic grounds - has helped to single out certain defining aspects of animation during its early days, i.e., between 1908 and the dawn of the "talkies," toward the end of the 1920s: a period that was marked - just as it was for live-action film - by changes in the entertainment industry's offerings ${ }^{\text {iv }}$ and by standardization at both the formal and the technical levels. Nevertheless, as this study will suggest, the moment at which this change occurred can be distinguished from the paradigms that accompanied it according to whether live-action or animated film is at issue. I will therefore begin with an overview of the careers and oeuvres of Emile Cohl, Marius O'Galop, and Robert Lortac in order to reconstruct some of the issues at stake during this first chapter in the history of animation, and only then, with reference to two sorts of visual display, serving two distinct functions, entertainment and instruction, will I show how this reconstruction may clarify our perception of the character of French film during its early years.

\section{A French school of film animation: Emile Cohl, Marius O'Galop, and Robert Lortac}

The comparativist approach - legitimized by the facts, since these three animators worked in conjunction with one another - is necessary because of the disappearance of a large part of Emile Cohl's filmography. Cohl claimed to have created more than three hundred animated films between 1908 and 1923, a hundred of which have been preserved; most of these were were produced by Gaumont and Pathé, having been conceived before he left for the United States, in 1912. This disappearance influences our understanding of his oeuvre, since it prevents us from examining changes over the long term. As a result, the confrontation between filmographies and the careers of these three animators is a prerequisite pertinent to the issue of methodology: it permits a recounting of the temporal reality of this first moment in the history of animated film -- which, though disrupted by the First World War, spans two decades, from 1908 to the eve of the talkies. In this manner one can fit any of several contextual elements - economic, ideological, aesthetic, and cultural - into its historical record.

To start with, Emile Cohl (1857-1938) claimed to have invented the animated cartoon, and his contemporaries did not contradict him. Today we know that this "invention" was the end product of a long series of wide-ranging experiments aimed at setting in motion the still images that photographs and drawings represent. However, Cohl's claim does not strike us as groundless, since, by helping to win for the process the recognition it deserved, he permitted it to develop and thus made possible its growth in France. Cohl may not have been the inventor of the animated cartoon but he was the first French maker of filmed drawings, in that he contributed to the animated-cartoon industry's rise by getting movie theaters to open their doors to it. Cohl was already fifty years old when he created his first films; before that, he had belonged to a bohemian group of artists known collectively as Les Incohérents and had worked not only as a caricaturist and 
a newspaper and children's-book illustrator but also as an actor and a photographer. From 1908 until the end of the 1920s he collaborated with the major motion-picture companies, Gaumont, Pathé, and Eclair, not only in Paris but also in New York, experimenting with a number of different techniques: the animation of drawings but also of paper cutouts and three-dimensional objects. Because he was paid according to the length of the footage - that is, the duration of the film - and the animated sequences were particularly time-consuming and tricky to achieve, since they were created one image at a time, his drawing sequences and animated objects were usually integrated into live-action footage. Such a mix of forms and techniques would not be perpetuated by Marius O'Galop and Robert Lortac, whose animated films were based exclusively on figure drawings that were then, as a rule, transformed into paper-cutout figurines.

Like Cohl, Marius O'Galop (1867-1946) frequented Montmartre's cabarets, ' and their illustrations appeared regularly in the same papers (and sometimes on the same page): newspapers ${ }^{\mathrm{vi}}$ but also children's magazines, such as Le Petit Journal Illustré de la jeunesse. O'Galop created about twenty films based on drawings or paper cutouts, which can be divided between themes with a didactic purpose (promoting good hygiene) and stories for children, the majority of which were commissioned as well as distributed by Pathé.

Like O'Galop, Robert Lortac (1884-1973), the youngest of the three animators under discussion, created for Pathé about twenty films, either with an educational purpose or as pure entertainment, before founding his own studio, and hiring both Cohl and O'Galop. Lortac launched a company in order to keep his craft afloat (as it were), threatened as it was by American cartoons flooding the French market and monopolizing the screens. During the next two years (1920-1922) he worked for the newspaper publisher Gaumont-Journal, specializing in utilitarian illustrations of news stories, before devoting his skills to animated commercials, a genre in which his studio excelled up until the beginning of the 1930s; at that point his studio suffered a business slowdown because the animated-film market dried up, no doubt largely on account of the arrival of the talkies. Henceforth he devoted himself to writing scenarios for comic strips (Bibi Fricotin, Les Pieds Nickelés)

\section{French film animation: Intermediality, seriality, and the industry of cultural products for children}

French film animation, as the oeuvres of Emile Cohl, Marius O'Galop, and Robert Lortac make clear, was the work of draughtsmen who applied their skills to a wide range of genres, providing not only pictures for children's books and illustrations for magazines but also images, still and animated, to be projected. For example, all three provided the review Après l'école aimed at a readership of schoolteachers, with a series of film images: that is, images that, having been printed on translucent paper, could be cut out and inserted into a slide projector. All sorts of new ways to use images, both printed and projected, followed, along with new ways to manipulate the various media at their disposal, leading these inventive artists to transpose a single image from one medium to another.

On the other hand, the adaptations made in the course of these transpositions indicate that they paid attention to the issues regarding the manner of representation. For example, O'Galop would modify the rhythm of a comic sketch depending on whether it was destined for print or projection; a reader can scan an entire set of cartoon panels simultaneously, whereas when the same images are projected serially the viewer's perception is controlled by an exposition that is serial in time as well as space. In some cases several illustrations were arranged in a row on elongated glass slides, the projector's light illuminating them one by one.

While the concept of intermediality helps to explain the diversity of these artists' 
approaches, that of cultural seriality, with which it is sometimes associated, poses a problem. Indeed, if one considers, for example, political or other news-related caricature, one immediately notices that this was Cohl's primary activity until, in the early 1900s, he shelved it to make room for cultural and sports caricature. According to Marcel Lapierre, ${ }^{\text {vii }}$ Cohl imported caricature into the film world when he started to provide illustrations for Eclair's film magazine; in the absence of any material proof of this activity, Lapierre's contention is substantiated by the fact that Cohl's personal archives contain a press card dated 1920 that identifies him as an Eclair-Journal employee.

What is more, such activity would not have been unique; the same year, Robert Lortac contributed a cartoon supplement, titled "Un Canard en ciné," to Gaumont-Journal. (The standard meaning of "canard" is "duck," but in this context it means "hoax.") The transfer from one medium to another, from print to film, was no doubt made possible thanks to the fact that legitimization on the basis of their cultural value was accorded to news-based drawings, which had previously been dissociated from other types of illustration. Be that as it may, a close look at le Canard en ciné reveals that the transposition to the screen of caricatures that were political or otherwise linked to current events was accompanied by drastic modifications. In fact, one cannot help but notice that if the visual bias of the drawings remains unchanged - it still features physiognomic caricature - the subject matter, be it the politicians campaigning for a baby boom or an anti-German complaint, in the aftermath of the Great War, is for the most part benign. The cultural link is illusory, since in shifting from the newspaper page to the movie screen, news in picture form abandoned both its journalistic and its political ambitions. In order to acquire legitimacy as a film genre, news in animated-cartoon form borrowed elements from established film genres: for instance, one finds a recurrent character akin to Chaplin and dubbed "Charlot k'Holmes."

These observations underline the fact that when one delineates a given cultural series in order to chart the formal phenomena of intermediality, one may end up misestimating the heterogeneity of these transfers, being as they are the result either of the industrial-production process or of a dissemination pattern particular to the arts and the techniques involved. This observation leads one to, for example, multiple adaptations of tales and fables which made the transition from book to film form, from printed to screen image, and from private presentation to public projection. There were many such processes, all necessarily influencing how the works in question were received, and, in spite of the appearance of continuity, inevitably modifying their content.

However, finding evidence of a discontinuity among the patterns of thought and vision, despite the fact that the subject matter remains unchanged, cannot completely conceal the fact that they were born of one and the same industry, for at the beginning of the 20th century all three innovators found work in a sector enjoying a steadily rising commercial success, and when they moved on to the film medium they took along the materials with which they were familiar. Emile Cohl animated toys -- dolls, wooden soldiers, marionettes, and puppets -- and devised scenarios featuring little children. Marius O'Galop recounts in picture books, on glass slides, and on film the adventures of one Dr. Méli-Mélo, a medical doctor who specializes in grafting animals. And Robert Lortac adapted for film the misadventures of a character nicknamed Toto or Touche-à-tout, a wellknown figure from 19th-century children's books and already included in the slide catalog of the publisher Lapierre.

Since the 19th century, and more specifically since the first issue of Le Magasin d'éducation et de récréation, (The Education and Recreation Store, or perhaps Storehouse) a review, published by Pierre-Jules Hetzel, that was the brainchild, as it were, of Jean Macé (founder of the Ligue de l'enseignement, or Teaching League), these cultural objects are aimed at being entertaining or instructive or a combination of the two, each justifying the other. Thus it is that animated film in its earliest days was notable for combining models whose function was either entertainment or 
instruction and was specific both to the illustration industry and to the cultural objects of childhood, with spectacular paradigms born of theatre and other performance arts:-a distinguishing feature that is not inconsequential when it comes to our understanding of the infancy of the Seventh Art.

\section{Animated movies and attractions: Entertainment models, or the grotesque applied to sight}

It seems that these illustrators evolved and without difficulty adapted their universes to each successive medium, but these transfers obliged them to modify their narrative rhythms, and repeatedly influenced their content. What, one wonders, was the effect on an artist's style when it passed from illustration to film? To put it another way, what happened to the line traced by the artist's pen when it shifted from page to screen? Cohl, O'Galop, and Lortac belonged to a tradition born of situational and portrait caricature, and which is based on what one might describe as bringing out the worst in the victim, by physical distortion, an established graphic technique that they bring with them to film; Cohl uses stop action to distort faces, at the mercy of metamorphoses; O'Galop invents hybrid creatures; and Lortac mistreats his characters by submitting them to physical afflictions imposed by modernity's mechanical character.

These representations draw their force from the art of the grotesque, as applied to caricature - an exaggeration of physical traits with the aim of creating something eye-catching. From this analysis one gathers that the clownish makeup and outrageous behavior that characterized the sort of films featured in variety shows were not derived exclusively from the popular stage, such as vaudeville, but rather from any of a number of performance arts that flourished around the turn of the century, since they conveyed a number of cultural practices, including caricature. In the case of any doubt about the validity of this proposition, one need only observe how situations and characters were handled in the three artists' filmographies.

In his first films - that is, before his departure for the United States, in 1912 - Emile Cohl mixed animated sequences and live-action scenes; the drawings were caricatural, and for his scenarios he used actors in greasepaint whose extravagant acting style was in line with what André Gaudreault and Tom Gunning have dubbed "le cinéma des attractions" and which in Cohl's case is evidence of his past experience as both an actor in and an author of vaudeville routines, since it included performing in the Grand Guignol under the direction of Oscar Méténier: a theatre-based form of the grotesque that, according to Cohl himself, distinguished him from Georges Méliès. In the prologue to Le Binettoscope (1910) he presented a character rigged out in a clown costume who when he gestures at a blank screen makes musical notes appear, which instantly turn into linedrawing caricatures. The gestural of this prologue is closely akin to what Méliès used in Le Mélomane (1903) when the eponymous character tosses musical notes onto a musical staff that together turn into an image of his face. In so doing, the animator set up, in opposition to the elegance of the magician, the grotesque of the clown, whose features are exaggerated by his bizarre makeup and costume: a character who functions as a sort of designated alter ego, and whom Cohl later used exactly the same way in a number of films that he made for Gaumont, including L'Hotel du silence (1908) and La Musicomanie (1910).

From that moment on, the grotesque representation of bodies and faces was, if one is to believe the prologue of Le Binettoscope, the film equivalent of print caricature; that such a process of exploitation occurred is confirmed by the character of Jobard as interpreted by Lucien Cazalis and created for Pathé (1911), a characterization that Laurent Le Forestier describes thus:

The basis of Cazalis's act is often a sort of progressive physical frenzy. Rather than employing realistic postures -- that is, rather than reducing gesticulation to the benefit of verbalization, the actor derives the bulk of his films' comic potential from his physical presence, sometimes even transforming his body into a sort of field test of his comic potential. ${ }^{\text {vii }}$ 
One finds this process of bodily distortion and deformation in the filmographies of Marius O'Galop and Robert Lortac, as well. To the aforementioned curious animal grafts of O'Galop's Dr. Méli-Mélo, in Touche-à-Tout ami des bêtes (1918), one might add the mistreatment suffered by the heroine of Bécassotte à la mer (1920). Bécassotte is saved from drowning by a fisherman who then, with the aid of a well pump, unceremoniously forces her to regurgitate not only all the salt water that she has swallowed but also a variety of items that had sunk to the ocean floor. Lortac, likewise, mistreats his creation Bigfellow - whose features bear an uncanny resemblance to his creator's - showing us close up his face twisted into a grimace of anger or pain; once again, a caricatural modification of physical traits is what gives the image its comic charge.

Thus it is that the earliest animated film shared with the movies projected in variety shows certain features derived from popular theater, such as the speech addressed directly at the audience. On the other hand, it introduced into the history of film a new category that one might designate by the term "the grotesque": an aesthetic ensemble in which appealing routines are placed cheek by jowl with figural caricature, whether the target be bodily gestures or facial expressions. Even so, animation during this period was not limited to pure entertainment; a number of films clearly had a pedagogical purpose, prompting us once again to wonder just how well we really understand this emerging art form.

\section{Animation and didactic models: To show is to teach}

Studies have tended to emphasize the presence in the earliest animated films of optical phenomena directly derived from toys such as chromatropes; ${ }^{\text {ix }}$ on the other hand, they have neglected to emphasize the presence in a number of films of didactic models derived from magiclantern sequences. These films show -- in contradiction of what has been written about them -- that pedagogical film was not a marginal genre that emerged after the Great War, following the publication of the results of the extra-parliamentary commission appointed by Paul Painlevé in $1915,{ }^{\mathrm{x}}$ since most of the animated movies made by Cohl between 1908 and 1910 evidently had a pedagogical purpose. In practice, it seems to have been attendant upon, even a middle ground between, the sort of movie destined for variety shows and the institutionalization of the narrative. Moreover, the didactic paradigm, as has already been noted, was operating in most of the cultural objects designed for children (scrapbooks and picture books, magic-lantern panes, printed and projected images) and resulted from the cultural socialization of images popularized in the 18th century, following the publication of engravings from the immense Encyclopédie compiled by Diderot and d'Alembert. The understanding of such images on the part of the entire society was undoubtedly was a specifically French phenomenon, rooted as it was in the Republican model propagated by the public-school system. From that point on, the stability and constancy of these ways of thinking might very well suggest that the marginalization of the instructive-movie genre resulted, instead, from ulterior industrial and institutional choices.

The institutionalization of the Seventh Art in France - that is, the standardization of moviemaking practices and the normalization of the language of films with a narrative aim - is said to have taken place around 1908, just when Emile Cohl created Fantasmagorie, his first animated cartoon. Animated film would thus have its own chronology, out of phase with that of live-action film, by a decade, because it seems that during the Great War the codes born of the variety show were shelved, to the benefit of syntactical criteria. The films made by Cohl for Gaumont between 1908 and 1910 comprise several unusual themes composed entirely of animated cartoons, in which he plays with metamorphoses and visual puns ${ }^{\mathrm{xi}}$ inspired by types of exposition specific to magiclantern sequences and storybooks for children. This pedagogical ambition could have hampered the rise of animation because in order to be read and understood the images have to be immobilized, and fixed images are scarcely compatible with the premise of the motion-picture medium. The earliest animation, as the filmography of Emile Cohl shows, thus borrowed most of its rhetorical 
models from instructional magic-lantern stories, and this educational purpose did not disappear after the Great War, but was found, if transformed, in the films promoting a healthful life style that O'Galop and Lortac made for Pathé. However, from then on their films worked by linking animated images with still shots, and thus served a double purpose: to entertain and, at the same time, to teach.

It would therefore appear that the institutionalization of the narrative of animated film in France operated on two planes, since it had to banish not only any and all elements derived from the world of the variety show but also the expository devices popularized by magic-lantern stories. For this reason the animators drew on printed imagery, particularly the kind of picture book in which the story progresses from panel to panel; thanks to the way close-ups connect with overviews, not to mention the dynamism of the draughtsmanship, they achieved the effect of a montage. This frameby-frame technique could be accurately described as essentially a motion-picture story once the animators gained their freedom from a didactic visual culture that was peculiarly French. At that point they imported into their films characters and situations previously used in comic strips and other print media, at the very moment that this practice was adopted on the other side of the Atlantic. It is therefore not surprising that Cohl, following his stay in New York, considered making a movie version of Les Aventures des Pieds Nickelés (1917-1918), a comic strip featuring thoroughly French characters. Nevertheless, as Cohl's own statements make clear, this change of paradigm was not achieved without difficulty, although he did his best to break free from the rigid rhetorical and formal dogma of the French educational system. Here is how he put it in 1925: "There is no doubt that, when it comes to its instructional potential, the animated cartoon has a promising future, and that it will serve as an assistant to the spoken word of the schoolmaster, providing it with both clarity and precision."xii

The educational films that Cohl made for Gaumont comprise historical subjects, practical and scientific matters simplified for the layman, but also arts and letters. It is possible but not necessary that they be accompanied by a lecturer's text, to highlight the discursive and lexical elements of the scenarios; they are equally suitable for an audience of children or of adults. L'École moderne (1909), co-directed with Étienne Arnaud, certainly constitutes a mise en abyme, or selfreflexive infinite regression, that is emblematic of what is at stake in the viewer's perception of the images that are projected. The drawing of an open book defines the frame; the left side is concealed by a page, otherwise blank, on which a name is written, while on the right a parade of historical figures, literary and political, advances, one by one: Washington, Shakespeare, Peter the Great, Napoleon, Dante, Bolivar, Cervantes, Goethe. Once each of them arrives at the foreground, he assumes a formal stance, as if posing for a sculpture (or a photograph), and we can see that his costume, accessories, and gestures are intended to symbolize his epoch and his role therein: ${ }^{\text {xiii }}$ for example, Goethe is portrayed holding a piece of parchment, whereas Dante, pensive, props his chin on one hand.

The discursive system reinforced by visual repetition allies film with a projection of fixed images in which the views can be used as the basis for an exercise in analysis - a deciphering of the meaning of gestures, for example - while praise of the arts, in return, contributes to a cultural legitimatization of film. Cohl usually depicted his subjects in a series of scenes (sometimes twenty, the number needed in the case of magic-lantern plates) that flash by on the screen, one after another, a slide changer controlling the movement. Les Chapeaux des Belles Dames (1909), for example, presents one by one, ladies adorned with elaborate headdresses; around each image he drew a decorative circle, and below provided the date that locates the fashion in history. Here, as with L'École Moderne, the drawing serves only two purposes: to decorate (the circle wreathing each of the figures) and to inform (the date provided below). En route (1910) sets out to be a history of methods of locomotion on land and sea and in the air; each picture presents, one by one, not only a horse, a chariot, a horse-drawn carriage, a stagecoach, an ox-cart, a train, a bicycle, and a car but 
also a fishing boat, a ship, a caravel, a paddle-wheel ship, a steamship, a battleship, a sailboat, a submarine, not to mention a bird, a hot-air balloon, a dirigible, and an airplane. This series of twenty images presents us with a transportation inventory, consisting mostly of human inventions, and leads to a moral presented in the last subtitle: "Man was no longer tired, but his world was," and we see the terrestrial globe overrun by all these inventions.

Sometimes these movies combine the expository style of the magic lantern with that of the variety show. L'Eventail animé (1909), for example, presents a series of painting-like scenes representing groups of illustrious women, among whom we recognize not only Eve, Sappho, Cleopatra, Messalina, and the lovely Aude of "Song of Roland" fame, but also La Parisienne, immortalized in song by the poet Delavigne; only the heaving of their chests betrays the fact that this is a motion picture and not a slide show. Another example of a work composed of a slideshow-like-series of pictures is Porcelaine tendre (1909), in which the chronological presentation of human figures has been replaced by figuration on the part of inanimate objects: a Roman clock, a Renaissance mug, a Louis XV candlestick, etc. Les Couronnes (1909) borrows its manner of representation and exposition not only from the magic lantern and the variety show but also from children's books; the film is both a history and a vocabulary lesson, in that the pictures are arranged in chronological order while the scenes represent well-known phrases featuring all sorts of crowns. Thus we get not only Christ with his crown of thorns, Romans with their crown of laurels, and newlyweds with their crown of orange blossoms but also those of actors, and even a crown-shaped loaf of bread offered by a rich man to a poor one; the closing frame shows a little girl rolling a hoop. This sort of vocabulary exercise also occurs in Les Générations comiques (1909); we watch drawings of fish metamorphose, one into another, their distinctive shapes serving as a teaching tool, until we arrive at a fisherman with his hook and line. ${ }^{\text {xiv }}$ Reve enfantins (1910) returns to the technique of découpage, or paper cutouts, presenting a series of flowers, identifiable because accurately depicted, down to their corollas.

In addition to films whose subject matter made them prone to pedagogical purposes, Cohl made others whose purpose seems to have been to popularize material from the humanities. Les Douze travaux d'Hercule (1910), for example, is a picture book recounting the exploits of the mythological hero; the artist's recourse to illustration is fully justified, in that it permits him to open a window onto a world of strange creatures and extraordinary situations. The literary ambitions of Cohl's adaptations of Le Petit Faust (1910) and Le Petit Chanteclerc (1910) are beyond doubt; the addition of the epithet "petit" signals not only that they are abridged versions of the stories but also that they feature animated dolls, and hence are designed for a young audience.

Cohl also tried his hand at films designed to encourage a healthful way of life. The purpose of Le songe d'un garçon de café (1910) was evidently to expose the evil effects of alcohol. A round white space is the setting for a series of bad dreams the meaning of which is easy to identify: the waiter is suffering from delirium tremens. The message, however, gets somewhat lost in all of the metamorphoses and grotesqueries in which Cohl indulges his talents. In fact, it seems that he got tired of doing these educational films, which no doubt were not his idea but commissioned by Léon Gaumont, who is known to have been at the origin of a military instruction film entitled La Bataille d'Austerlitz. The last film that Cohl made for Gaumont, La Musicomanie, strives to caricature or render grotesque pedagogical aims themselves. The film starts out like an instructional one, revealing, one by one, in drawings of coats of arms, each of them assigned a date, portraits of famous musicians (Wagner, Bach, Mozart, ); then suddenly two characters with clownish features and extravagant gestures - "joyeux fêlés" ("joyous loonies") to quote Cohl - appear, who use musical instruments to destroy, before our very eyes, the space in which the scene is being enacted. It was this film that provoked the rupture between Cohl and Gaumont.

Marius O'Galop and Robert Lortac, too, signed their first contracts for films with a didactic 
purpose: a good ten of them, on how to prevent syphilis, tuberculosis, and alcoholism, the earliest of which were undertaken during the Great War under the scientific guidance of Dr. Jean Comandon, the inventor of microcinematography; many of them incorporated live-action footage of microbes. These topics proved to be particularly interesting in that, thanks to their hybrid forms, they function at several levels of monstration, and thus can be called transitional. If the earliest were intended for an audience of soldiers, those that followed were aimed at a larger public; that they remained in the Pathé catalog clearly indicates that they enjoyed a wide distribution. The scenario of O'Galop's On doit le dire (1918) features stricken soldiers stricken with syphilis, whereas he introduces women and children into the story line of La Mouche (1919) in order to make them aware that contagious diseases are spread by germs. It is difficult to distinguish which of the two men was responsible for the films they made in 1918; the same skeleton plays a role in Lortac's Pour résister à la tuberculose soyons forts and his La tuberculose menace tout le monde and also in O'Galop's Le taudis doit être vaincu. Their sets were minimal, consisting of a single space and a frontal camera angle, in which the characters perform a physical or verbal joust. The film's message is conveyed by means of comic-strip-style speech bubbles, while the audience is systematically called upon as witness, with the purpose of garnering its agreement. This sort of call to arms is also manifest in the frequent use of the musical staff, which seems to invite the public to take up, in chorus, the notes of a song. In O'Galop's On doit le dire (already mentioned)-a few rare instances in which facial expressions define a role conjure up a distant connection with caricature, in that a close-up, live-action shot of the distorted features of a syphilis victim functions as a caricature. In subsequent films the device of addressing the audience diminished - the story line had to justify the practice - until, at some point during the $1920 \mathrm{~s}$, it disappeared altogether. For example, On doit le dire opens with the drawing of a man, presumably a lecturer, who, pointing his finger at the audience, seems to be sermonizing them from behind his lectern: a complex story line, in that it presents in parallel two levels of fiction and thus, by extension, two time schemes: the one in which the lecturer exists (present time, relative to the audience) and another one in which the misadventures of the two principal characters take place. We are faced with an equally intricate time scheme in O'Galop's L'oubli par l'alcool (1918), in which we follow a man's physical deterioration, only for it to prove to be nothing but a bad dream brought on by drink. Thus, in spite of a steady increase in the integration of the narrative, these films ware still deeply influenced, when it comes to their scenarios, by their original model, the variety show. Because our three animators had yet to appreciate the idea that there is the space offscreen to consider, they neglected stage action that moves horizontally, a pattern that was to become evident during the decade of the 1920s and was specific to animated cartoons. Nevertheless, the fact that from this point on they had recourse to a method of creating syntactic cut-outs, indicates that animated cartoons would from then on be an integral element of the narrative-film genre.

\section{The early years of animated film, or New perspectives on film in France}

Animated film in the early period under consideration here prompts various thoughts about this meeting place of multiple cultural series, a particularity that is not without consequences when it comes to our understanding of the historiography of film. The earliest animated film was the work of illustrators who, using stop-action camerawork and the frame-by-frame recording of images of objects and drawings, composed or invented the illusion of movement thanks to an in-phase breakdown modeled partly on toys that generated optical illusions. Being caricaturists, they adapted the personal (as opposed to situational) caricature to stage practices associated with the variety show, resorting to the mistreatment of bodies and faces, a practice derived from the artistic genre known as the grotesque. Being as they were illustrators, finding work in the illustrated press and in the children's-book and -toy industry, they brought to filmmaking a new dialectic between recreational and educational functions. This background of theirs permitted them, first of all, to prevent the abandonment of stop action - Georges Méliès would soon get carried away with it - by turning to the didactic model provided by magic-lantern scenarios. And even as the variety-show 
movie died out, to the benefit of a syntactical and narrative evolution in the language of cinematography, they found in a picture album or a comic strip an art of composition by imagery which permitted them to to figure out, once again, how to keep going. Thus the history of animated film in France appears to be a long series of adaptations to ever-shifting paradigms of legitimization, and shows how, thanks to their inventive resources, this first generation helped to secure for animation its rightful place in the world of film.

\footnotetext{
${ }^{\mathrm{i}}$ For the record, among French studies is the pioneering work of Lo Duca, Le dessin animé (Paris, Prisma, 1948; reprint, Paris: Editions d'aujourd'hui, 1982).

ii Thus, in more than one respect, Donald Crafton's monograph on Emile Cohl, Emile Cohl, Caricature, and Film (Princeton: Princeton University Press, 1990), placing the filmmaker in his cultural context, remains a model of the genre.

iii See two works edited by Valérie Vignaux: "Emile Cohl," 189553 (December 2007): 360, and "Marius O'Galop and Robert Lortac," 189559 (December 2009): 348.

${ }^{\text {iv }}$ See André Gaudreault and Tom Gunning, "Le cinéma des premiers temps. Un défi à l'histoire du cinéma," Histoire du cinéma. Nouvelles Approches, ed. Jacques Aumont, André Gaudreault, and Michel Marie (Paris: Presses de la Sorbonne Nouvelle, Colloque de Cerisy, 1989), 49-63.

v Both of them provided illustrations to Montmartre, co-authored by Georges Renault and Henri Château (Paris: Flammarion, 1897).

${ }^{\text {vi }}$ See Raymond and Jean Hector, "Emile Cohl et O'Galop à La Dépêche du Midi," Archives 20 (February 1989).

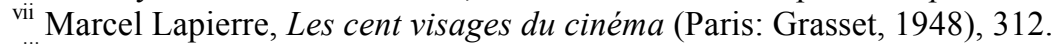

viii Laurent Le Forestier, "Emile Cohl chez Pathé: l'expérience burlesque" in "Emile Cohl," ed. Valérie Vignaux, 1895 , 53 (Decembre 2007), 190.

${ }^{\text {ix }}$ The chromatrope is a pane of lamp glass composed of a stack of several colored disks ornamented with motifs, each motif slightly out of phase with the others. Placed in front of a lit lantern and set in motion by the turning of a handle, the glass, thanks to the interplay of the stacked disks, produces an infinite number of visual effects, along the lines of those produced by a kaleidoscope.

${ }^{\mathrm{x}}$ This commission led to the establishment in 1920 of the film service at the Musée pédagogique, an establishment that, under the supervision of the Department of Public Education, centralized the nationwide distribution of lantern-glass panes with an educational purpose; this service was soon followed by the establishment of film libraries funded by the Departments of Public Health and of Agriculture. See Valérie Vignaux, Jean Benoit-Lévy ou le corps comme utopie, une histoire du cinéma éducateur dans l'entre-deux-guerres en France (Paris: AFRHC, 2007).

${ }^{x i}$ There are numerous visual puns in Cohl's oeuvre; moreover, he constructed rebuses that were run in newspapers. The most famous of these is undoubtedly the one which, in Le Peintre néo-impressionniste (1910), permitted him to portray Léon Gaumont as a camel (chameau being a popular term for a grouch). At first we see a boat flying the company's trademark, whereas the subtitle indicates that what we are looking at is a "desert craft," and indeed, by means of a series of metamorphoses the bateau turns into a chameau.

xii J.-B. de Tronquières (Emile Cohl), "Dessins animés," Larousse mensuel 222 (August 1925) in "Emile Cohl," Valérie Vignaux, ed., op.cit. : 307-312.

xiii Cohl had already used this sort of symbolic characterization in the portrait-type (as opposed to situational) caricatures that appeared in the review Hommes d'aujourd'hui (1878-1899), in which each individual is accompanied by an identifying object.

xiv "Crown" wordplay is also found in one of Cohl's burlesque films starring a certain Jobard, Les Générations comiques (1909), in which our hero inadvertently transforms one circular object into another: automobile wheel into funeral wreath into rond-de-cuir (literally, "round piece of leather," but figuratively a pen-pusher) into ring-shaped load of bread.
} 